\title{
Applied Entomology and Zoology Vol. 48, No. 2 目次
}

(2013 年 5 月 25 日発行)

\section{REVIEWS}

Different effects of climate change on the population dynamics of insects

K. Kiritani 97

[気候変動が昆虫個体群動態に及ぼす様々な影響

桐谷圭治] 97

Notes on entomophagy and entomotherapy generally and information on the situation in India in particular

V. B. Meyer-Rochow · J. Chakravorty 105

[昆虫食と昆虫療法に関する一般的な知見と特にインドにおける現状

Victor Benno Meyer-Rochow • Jharna Chakravorty] 105

\section{ORIGINAL RESEARCH PAPERS}

Field trials of synthetic sex pheromone lures for the large cabbage-heart caterpillar moth, Crocidolomia pavonana (Lepidoptera: Crambidae) in Indonesia

T. Adati $\cdot$ S. Kato $\cdot$ W. Toriumi $\cdot$ K. Kawazu $\cdot$ W. Susila $\cdot$ K. Sumiartha $\cdot$ G. Suastika $\cdot$ Dadang $\cdot$ I. M. Samudra 113

[インドネシアに怙けるケブカノメイガ Crocidolomia pavonana (チョウ目：ツトガ科)のための合成フェロモンルアーの野外試験 足達太郎 · 加藤晋一 - 鳥海 航 - 河津 圭 - Wayan Susila $\cdot$ Ketut Sumiartha $\cdot$ Gede Suastika $\cdot$ Dadang $\cdot$ I Made Samudra $] 113$

Genetic variation of two apterous wasps Haplogonatopus apicalis and H. oratorius (Hymenoptera: Dryinidae) in East Asia

T. Mita $\cdot$ S. Sanada-Morimura • M. Matsumura • Y. Matsumoto 119

[翅を持たない寄生蜂, クロハラカマバチ Haplogonatopus apicalis とトビイロカマバチ H. oratorius (ハチ目：カマバチ科)の東アジ アに打ける遺伝的変異

三田敏治・真田幸代・松村正哉・松本由記子］ 119

Dimerization and proper degradation of BmNPV IE2 are required for efficient virus growth in larvae of Bombyx mori (Lepidoptera: Bombycidae)

A. Tsuchida $\cdot$ G. Ishihara $\cdot$ T. Shimada $\cdot$ S. Katsuma 125

[BmNPV IE2 の 2 量体化と分解はカイコ (チョウ目：カイコガ科)

幼虫でのウイルス増殖に関与する

土田歩未·石原玄基・嶋田 透·勝間 進］ 125

Overseas migration of the common cutworm, Spodoptera litura (Lepidoptera: Noctuidae), from May to mid-July in East Asia

S. Tojo $\cdot$ M. Ryuda $\cdot$ T. Fukuda $\cdot$ T. Matsunaga $\cdot$ D.-R. Choi $\cdot$

A. Otuka 131

[東アジアで 5 月から 7 月中旬に起こるハスモンヨトウ Spodoptera litura (チョウ目：ヤガ科)の海を越えた移動

藤條純夫 ·龍田勝輔 - 福田 健 - 松永禎史 - 崔 東魯 - 大塚 彰] 131

Food exchange behavior between multiple founding queens of Polyrhachis moesta (Hymenoptera: Formicidae) changes during hibernation

A. Hashimoto $\cdot$ K. Sasaki $\cdot$ S. Koyama • T. Satoh 141

[チクシトゲアリPolyrhachis moesta (ハチ目：アリ科)の多雌創設

女王は越冬中に餌交換行動を変える

橋本絢乃・佐々木謙・小山哲史・佐藤俊幸］ 141

A comparison of the larval overwintering biology of the striped stem borer, Chilo suppressalis (Lepidoptera: Crambidae), in rice and water-oat fields

N. Ding - P. Dalin - Q.-H. Zhu - W.-H. Ma - F. Zhu - X.-P. Wang 147

[イネとマコモ戋場に打けるニカメイガ (チョウ目：ツトガ科)の 幼虫越冬の特性比較

Nan Ding · Peter Dalin $\cdot$ Qing-Hua Zhu $\cdot$ Wei-Hua Ma $\cdot$ Fen Zhu • Xiao-Ping Wang] 147

Molecular identification and ecological characteristics of two cryptic lineages within a cosmopolitan aphid pest, Brachycaudus helichrysi (Hemiptera: Aphididae)

J. Piffaretti · J.-P. Rossi · F. Vanlerberghe-Masutti · G. Genson •

A. C. d'Acier • E. Jousselin 155

[汎世界的害虫, ムギワラギクオマルアブラムシ (カメムシ目 : ア ブラムシ科) に打ける 2 つの隠蔽系統の分子情報による識別と生 態学的特徴

Joséphine Piffaretti - Jean-Pierre Rossi - Flavie Vanlerberghe-Masutti • Gwenaelle Genson • Armelle Coeur d'Acier • Emmanuelle Jousselin] 155

Application of a powdered artificial diet to promote the establishment of the predatory bug Geocoris varius (Hemiptera: Geocoridae) on strawberry plants

K. Igarashi $\cdot$ M. Nomura $\cdot$ S. Narita 165

[捕食性天敵オオメカメムシ (カメムシ目：オオメカメムシ科）の 
イチゴ株への定着性向上のための粉末人工飼料の適用

五十嵐清晃・野村昌史・成田聡子] 165

Long-chain alkanes: allelochemicals for host location by the insect pest, Epilachna dodecastigma (Coleoptera: Coccinellidae)

N. Sarkar • A. Mukherjee • A. Barik 171

[長鎖アルカン：テントゥムシ科の一種 Epilachna dodecastigma(コ ウチュウ目：テントウムシ科) の寄主発見行動に利用されている アレロケミカル

Nupur Sarkar • Abhishek Mukherjee • Anandamay Barik $] 171$

The effects of foods consumed after adult eclosion on the mate-searching behavior and feeding preferences of the white-spotted longicorn beetle Anoplophora malasiaca (Coleoptera: Cerambycidae)

H. Yasui • N. Fujiwara-Tsujii 181

[羽化後の餌植物がゴマダラカミキリ Anoplophora malasiaca (コウ チュウ目：カミキリムシ科）の配偶者探索行動扎よび摂食選好性 に与える影響

安居拓恵 $\cdot$ 辻井 (藤原) 直] 181

Occurrence of the exotic predatory ladybird Platynaspidius maculosus (Coleoptera: Coccinellidae) in citrus groves in Shizuoka City, Central Japan: seasonal prevalence of adults captured on sticky traps

S. Kaneko 189

[外来種モンクチビルテントウ Platynaspidius maculosus (コウチュ ウ目：テントウムシ科）の静岡市内のカンキッ園に打ける発生：

粘着トラップにおける成虫の捕獲消長

金子修治] 189

Economic thresholds of Thrips palmi (Thysanoptera: Thripidae) for eggplants in a greenhouse

R. Yadav ・ N.-T. Chang 195

[ハウス栽培ナスに打けるミナミキイロアザミウマ（アザミウマ 目：アザミウマ科) の経済的許容限界

Ramchandra Yadav $\cdot$ Niann-Tai Chang] 195

Ethiprole resistance in Nilaparvata lugens (Hemiptera:
Delphacidae): possible mechanisms and cross-resistance P. Punyawattoe $\cdot$ Z. Han $\cdot$ W. Sriratanasak $\cdot$ S. Arunmit $\cdot$ J. Chaiwong $\cdot$ V. Bullangpoti 205

[トビイロウンカ（カメムシ目：ウンカ科）のエチプロール抵抗 性：そのメカニズムと交差抵抗性

Pruetthichat Punyawattoe $\cdot$ Zhaojun Han - Wantana Sriratanasak Sukanya Arunmit · Jintana Chaiwong • Vasakorn Bullangpoti] 205

Canopy-related adult density and sex-related flight activity of Monochamus alternatus (Coleoptera: Cerambycidae) in pine stands

H. Sugimoto $・$ K. Togashi 213

[マツ林に抢けるマツノマダラカミキリ Monochamus alternatus (コ ウチュウ目：カミキリムシ科) 成虫の林冠内密度と雌雄の飛翔活 動性

杉本博之・富樫一巴］ 213

\section{TECHNICAL NOTES}

Aphid consumption and residence time of larvae of flightless lady beetles, Harmonia axyridis (Coleoptera: Coccinellidae), on aphid-infested plants

S. Nakayama $\cdot$ J. Takatsuki $\cdot$ T. Seko $\cdot$ S. Ando $\cdot$ K. Miura $\cdot$ T. Miyatake 223

[人為的にアブラムシを導入した植物上における飛ばないナミテ ントゥ Harmonia axyridis (コウチュウ目：テントウムシ科）にお ける幼虫のアブラムシ捕食量と滞在時間

中山 慧 · 高月淳一 - 世古智一 ·安藤彰太郎 · 三浦一芸 · 宮竹貴 久] 223

A convenient route for synthesis of 2-isopropyliden5-methyl-4-hexen-1-yl butyrate, the sex pheromone of Planococcus kraunhiae (Hemiptera: Pseudococcidae), by use of $\beta, \gamma$ to $\alpha, \beta$ double-bond migration in an unsaturated aldehyde

J. Tabata 229

[不飽和アルデヒドの二重結合転移反応を利用したフジコナカイ ガラムシ (カメムシ目：コナカイガラムシ科) の性フェロモン・ 2-イソプロピリデン-5-メチル-4-ヘキセン-1-イル=ブチレートの 合成方法

田端純］ 229 